\title{
Final Technical Brief / DOE Grant DE-FG03-96 ER 62219 Computational Study of Electron Tunneling in Proteins
}

\author{
Jeffrey J. Regan \\ Division of Chemistry \\ California Institute of Technology \\ Grant period: $9 / 1 / 96$ to $8 / 31 / 98$
}

3rd March 1999

Electron transfer (ET) processes in proteins are characterized by the motion of a single electron between centers of localization (such as the chlorophyll dimer in photosynthetic reaction centers). An electronic donor state $D$ is created by the injection of an electron or by photo-excitation, after which the system makes a radiationless transition to an acceptor state $A$, resulting in the effective transfer of an electron over several angstroms. The experimental and theoretical understanding of the rate of this process has been the focus of much attention in physics, chemistry and biology.

\section{Electron Transfer Tubes}

The initial work funded by the grant included the development and computational testing of the electron transfer tube model of electron transfer. This model is based on the idea that the detailed arrangement of atoms and bonds in protein media can be a primary deteriminant of electron transfer rates.

Electron transfer tubes are made up of specific sequences of bonding orbitals. A given donor and acceptor pair in a molecular system can be connected by more than one ET tube. Each tube is associated with a specific coupling factor that contributes to the overall electron transfer coupling between the donor and acceptor. Moreover, these different couplings interfere in quantum mechanical fashion; adding more tubes does not always enhance electronic coupling, it can also degrade it.

Tubes are a useful concept in that they can be created or disrupted by protein mutation, thus offering a way to not only test the theory, but feed experimental numbers into the theory.

The attached reprint "Electron Transfer Tubes" by J.J. Regan and J.N. Onuchic (from Electron Transfer: From isolated Molecules to Biomolecules, 1999 John Wiley \& Sons - see attached) contains a detailed discussion of the theory and its application to the interpretation of a series of electron transfer experiments performed in the protein Azurin.

\section{Cytochrome $c$ Oxidase}

Cytochrome $c$ oxidase, a membrane-based enzyme, is a terminal component in the respiratory chain in mitochondria and many bacteria. It catalyses the reduction of molecular oxygen to water, while at the same time pumping protons across the membrane to establish a voltage across it. The central question is how does the protein arrange to deliver electrons and protons to their various destinations? The mechanism of this process is still not fully understood, despite the fact that the enzyme has been crystallized and subjected to X-ray studies.

In Pathways for Electron Tunneling in $\mathrm{Cy}$ tochrome $c$ Oxidase by J.J. Regan, B.E. Ramirez, J.R. Winkler, H.B. Gray and B.G. Malmström ( $J$. Bioenergetics and Biomembranes, v30:1, p35, 1998 - see attached), the electron transfer part of the question is studied using the tube model on the structure obtained from crystallography.

The paper offers a wiring diagram for the enzyme that can be tested experimentally through the use of site-directed mutagenesis, and suggests ways in which the electron transfer can gate the proton transfer and vice versa.

\section{Papers attached}

Two papers describing these results in more detail are attached. ,

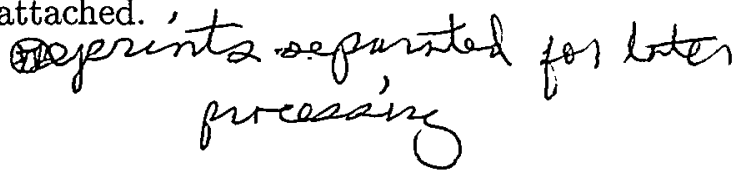




\section{DISCLAIMER}

This report was prepared as an account of work sponsored by an agency of the United States Government. Neither the United States Government nor any agency thereof, nor any of their employees, make any warranty, express or implied, or assumes any legal liability or responsibility for the accuracy, completeness, or usefulness of any information, apparatus, product, or process disclosed, or represents that its use would not infringe privately owned rights. Reference herein to any specific commercial product, process, or service by trade name, trademark, manufacturer, or otherwise does not necessarily constitute or imply its endorsement, recommendation, or favoring by the United States Government or any agency thereof. The views and opinions of authors expressed herein do not necessarily state or reflect those of the United States Government or any agency thereof. 


\section{DISCLAIMER}

Portions of this document may be illegible in electronic image products. Images are produced from the best available original document. 